\title{
Conservation and Management of Archaeological Monu- ments and Sites in Greece and Turkey: A Value-Based Approach to Anastylosis
}

\author{
Kalliopi Vacharopoulou \\ Institute of Archaeology, UCL
}

\begin{abstract}
Heritage management and monument conservation play a significant role in the preservation of archaeological heritage. Anastylosis, a process with a long history in the Mediterranean region, is discussed with relevance to current debates concentrating on concepts of value-based approaches. Examination of the diverse values that may be attributed to monuments provides an insight into the evolution of ideas in heritage management, conservation and restoration practices. In the current theoretical framework the concept of values, as attributed by all stakeholders, and its application when preserving archaeological heritage, are constantly debated. The participation of stakeholders in the process of value identification is considered fundamental by heritage management experts. This paper presents the findings of a survey conducted to collect the opinions of anastylosis and restoration professionals, with reference to case studies on a number of monuments subjected to anastylosis in Greece and Turkey, highlighting the importance of assessing values in order to establish the appropriate type and extent of intervention. The paper concludes that a value-based approach to decision-making and planning for anastylosis, or any other form of architectural conservation, is crucial for preserving monuments in a way that satisfies those who want to experience and benefit from heritage.
\end{abstract}

Keywords

Anastylosis, conservation, Greece, heritage management, Turkey, values

\section{Introduction}

Heritage management and monument conservation are interrelated fields that play a significant role in the preservation of archaeological heritage. Debates arise with regard to theoretical and practical matters of conservation, management, planning and implementation. Currently, ideas of value-based and holistic management approaches are dominant within conservation disciplines, with values defined in this paper as "the characteristics and qualities of things or objects" (Mason and Avrami 2002: 15). Values are not embodied in the objects as such, but are attached to them by various groups of people or individuals.

Anastylosis - the reassembly of a monument using its existing ruined parts (ICOMOS 1964) - is a significant method of intervention with a long history, having been implemented in monuments of the Mediterranean region since the $19^{\text {th }}$ century. In the $20^{\text {th }}$ century, the international conservation charters that established the theoretical framework for intervening in and managing heritage endorsed anastylosis as a justified form of architectural conservation, thus involving anastylosis in the same debates as conservation and management practices more generally.

This paper explores how values of monuments and sites are identified and assessed in the preservation process, and in turn how these are debated and applied to anastylosis of classical monuments in Greece and Turkey. The ultimate aim is to highlight the im- 
portance of assessing a broad range of values attributed to an archaeological site in the decision-making and planning processes for anastylosis.

The paper is divided into three main sections. The first part introduces the concept of values and the cultural significance of archaeological sites and monuments. This provides the broader theoretical framework within which anastylosis discourse fits. The second part explores the role of the value-based approach in the decision-making process regarding the practice of anastylosis as a conservation policy. The role of value-attribution is explored through a review of literature produced on the subject, an examination of eight case studies, and a synthesis of the opinions of heritage specialists (architects, archaeologists, civil engineers, restorers and architectural conservation consultants) from a survey undertaken as part of my doctoral research on anastylosis. The final section offers some suggestions for better practice in the application of anastylosis based on the value-led approach to heritage management.

\section{The Current Situation in Heritage Management and Debates on Values and Value-} Based Approaches

Today, the management of heritage sites is considered fundamental to their preservation for the future (Kristiansen 1989: 28-29). Conservation of heritage provides us with a greater understanding of our identity, of cultural continuity, of the human condition and of our place in the world and in time (Mason and Avrami 2002: 13). There is no perfect system of heritage management, however, because practice must adapt to changes in the economic, political, social and physical environment (Hall and McArthur 1998: 220). It is a complex process that involves determinations about what constitutes heritage, how it is used, cared for and interpreted, by who and for whom (Avrami et al. 2000: 7). It should be understood that heritage exists because of the values people attach to it (Hall and McArthur 1998: 220), and in this sense heritage belongs to the societies that value it (Pearson and Sullivan 1999: 33).

The decision-making process in conservation is defined by cultural contexts, societal trends and political and economic forces. The attribution of values to monuments can be seen to aid this process, as it promotes a ranking of significant features with some values given precedence over others, and transforms objects and places into 'heritage'. The ultimate aim of conservation is to maintain the values embodied by heritage - and attributed to it by those whom it is intended to benefit - and physical intervention is the means to achieve this (Avrami et al. 2000: 7). Values have been classified as aesthetic, religious, political, economic, historic, artistic, scientific, cultural and contextual (Pye 2001: 60). Yet such distinctions are not always sharp: value-types may overlap in particular contexts and become interdependent or inseparable from one another. An additional drawback to the use of a valuing system is that no typology can accurately describe the values of every site (Mason and Avrami 2002: 16).

Cultural significance encapsulates the multiple values ascribed to objects, buildings or landscapes (Avrami et al. 2000: 7). It may be "personal, local, regional, national or international; academic, economic or social" (Clark 2001: 12). Generally, values and cultural significance cover both tangible and intangible aspects of heritage (Pye 2001: 58). 
Given the above, values can be implemented to set priorities in distinguishing what might be conserved from what will not (Clark 2001: 12), and in establishing the extent and nature of interventions (Feilden 1994: 6). Hence, values first need to be identified and understood, so as to ensure that heritage ownership is a rich experience for stakeholders, while preserving heritage for the future (Hall and McArthur 1998: 220).

The diversity of value-types can create conflicts over their prioritisation. Values are often prioritised according to the interests of various groups (such as archaeologists, national authorities or tourism operators), though at times these refute the legitimate prioritisation of values by other groups, for example local communities (Pearson and Sullivan 1999: 17-20; De la Torre and MacLean 1997: 12).

Decisions on whether to conserve monuments can be limited by prevailing circumstances, such as land ownership, financial needs, development pressures, environmental features and claims by various groups to use heritage for symbolic purposes (Mason and Avrami 2002: 14). Economic factors influence the decision-making process, shape government heritage policies and enable conservation work through financing (Mason 1999: 2, 4). Equally, jobs, income, wealth and taxes can be generated through heritage (Bluestone et al. 1999: 20). Additionally, recent theories of heritage interpretation and preservation have emphasised the placing of monuments and objects in their historical and cultural contexts (Carter and Grimwade 1996: 53). Consequently, as Philippot maintains, conservation cannot be undertaken unless the relationship between context, preservation and modern use is considered from both theoretical and practical standpoints. Balancing conservation demands and public rights is difficult, but it can secure the future of the past (Melucco Vaccaro 1996: 205-206).

\section{Anastylosis and Values}

Heritage is valued in many ways, and the sense of value is driven by diverse motivations (economic, political, cultural, spiritual and aesthetic). These different ways of valuing lead to different approaches to the preservation of heritage, and the appropriateness of each intervention depends upon the values prioritised by the community, or 'stakeholders' (professionals, public, government, etc.) involved (Avrami et al. 2000: 8).

In anastylosis numerous values are attributed to monuments, only some of which are considered significant during the decision-making process. A synthesis of responses by professionals participating in an anastylosis survey, together with an examination of case studies from Greece and Turkey, allows an examination of value-based approaches in anastylosis. This classification of values is largely based on the Burra Charter (ICOMOS 1999) and the Getty Conservation Institute approach (Avrami et al. 2000). The survey was conducted through interviews and written questionnaires covering all aspects of anastylosis, and was circulated to anastylosis professionals and heritage specialists. The case studies are as follows:

1. The Erechtheion, Athenian Acropolis (Fig. 1)

2. The Parthenon, Athenian Acropolis (Fig. 2)

3. Stoa of the Avaton, Epidaurus (Fig. 3) 
4. Propylon of the Gymnasium, Epidaurus (Fig. 4)

5. Stoa of the Acropolis of Lindos, Rhodes (Fig. 5)

6. The Celsus Library, Ephesus (Fig. 6)

7. The Trajaneum, Pergamun (Fig. 7)

8. The Hellenistic Nymphaeum at Saglassos

\section{Scientific and Research Values}

According to professionals interviewed for the survey, scientific and research values were considered to be significant in evaluating the need for anastylosis applications. The assimilation of scientific methodologies by archaeology during the 1970s probably initiated this regard for scientific values in conservation (Jokilehto 1999: 299-300). In addition, archaeological sites are valued as records of the past and the information contained within them has potential value for research, education and the generation of knowledge (Mason and Avrami 2002: 17). As such, scientific and research values have been prioritised in the anastylosis of the following case-studies: the Parthenon in the Athenian Acropolis; the Stoa of the Acropolis of Lindos in Rhodes; the Hellenistic Nymphaeum at Sagalassos; the Celsus Library at Ephesus; and the Trajaneum at Pergamun.

\section{Architectural and Archaeological Values}

Participants in the survey endorsed the architectural and archaeological values of monuments subjected to anastylosis. The involvement of architects in such conservation (Philippot 1996: 218-219) sparked interest in architectural attributes, and monuments with exceptional architectural features - such as those of Epidaurus and the Athenian Acropolis, as well as the Celsus Library - were often the first to be considered for anastylosis. Archaeological attributes, such as evidence for past functions and practices, are the most important values to be identified and enhanced through anastylosis. For instance, the Avaton of Epidaurus is a source for the study of ancient medical practices, and the Erechtheion of the Athenian Acropolis for that of cults and religious functions.

\section{Historical Values}

By virtue of representing the passage of time in material form, heritage has historical value (Mason and Avrami 2002: 16). According to the survey participants, monuments hold significance for both the history of art and the preservation of historical memory. They are related to the contributions of all periods, including past interventions. In the cases of Epidaurus, Lindos, the Athenian Acropolis, Sagalassos and Ephesus, perceived historical significance was of prime importance in deciding to conserve the monument through anastylosis.

\section{Symbolic Values}

Symbolic values refer to the capacity of a heritage site for endorsing group identity and other social relations built through spiritual and cultural associations with the site (Demas 2002: 37; Mason and Avrami 2002: 17). This type of value is particularly relevant to the Acropolis monuments, which in the early $20^{\text {th }}$ century became revered as symbols of the resurrection of the Greek nation at the end of the Ottoman occupation (Jokilehto 1999: 89).

These anastylosis interventions favoured recourse to the glorious ancestral inheritance 


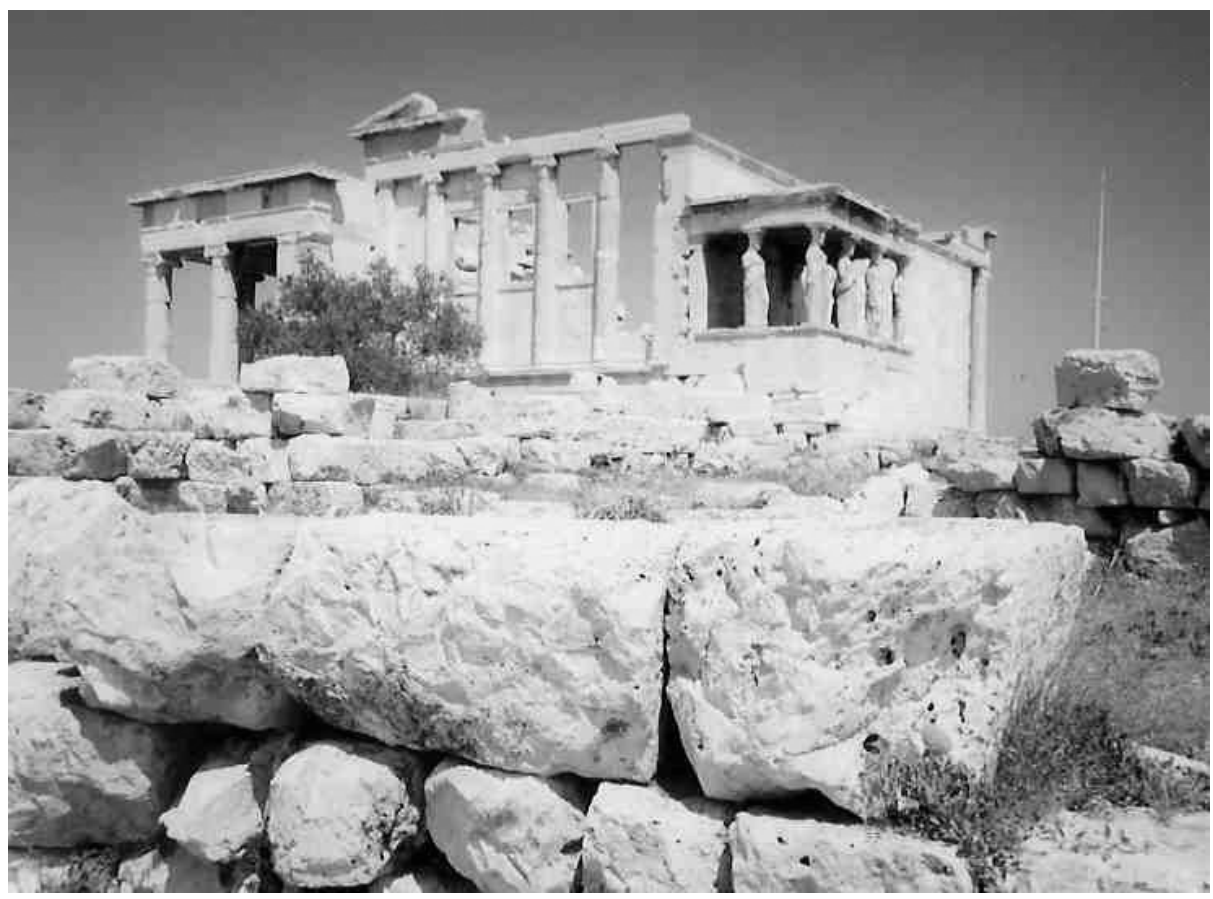

Figure 1. View of the restored Erechtheion on the Acropolis of Athens (2002).

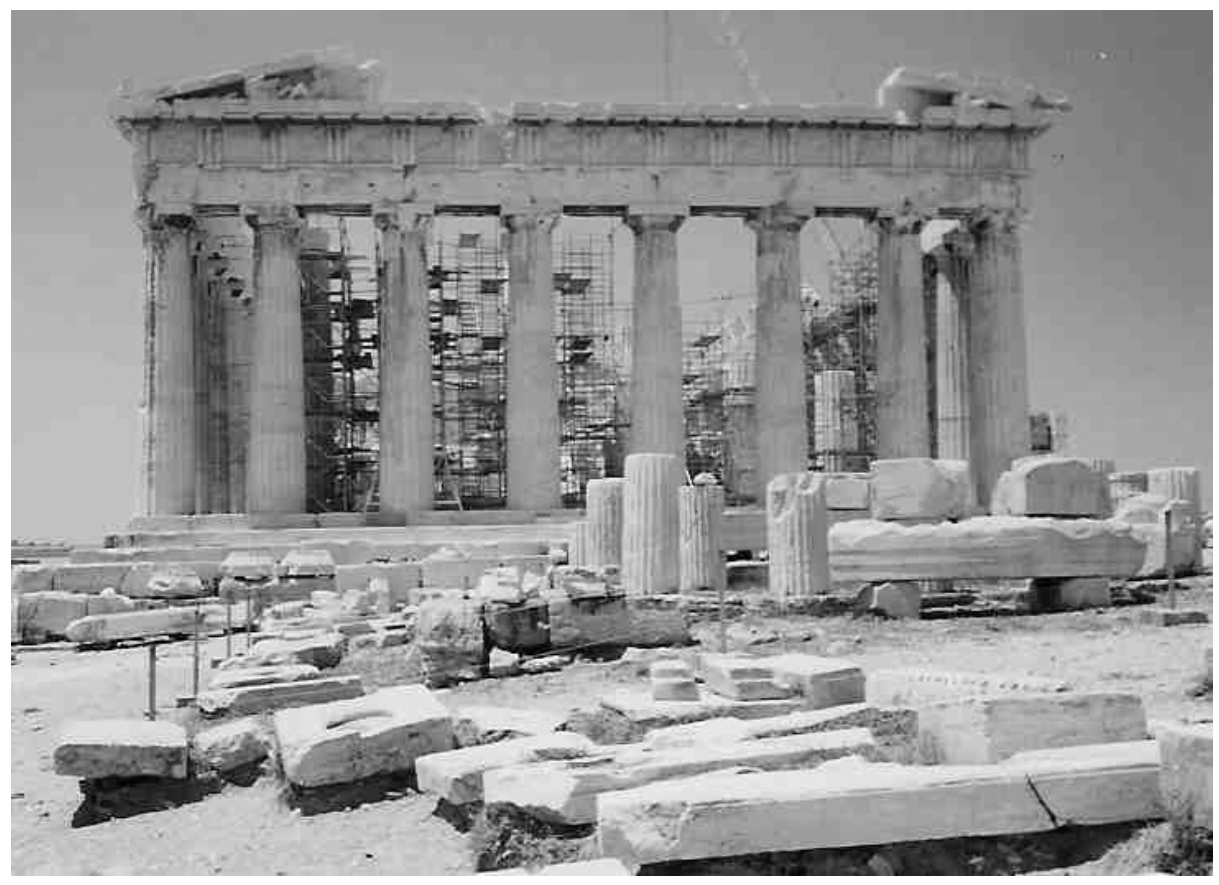

Figure 2. The east side of the Parthenon on the Acropolis of Athens during its anastylosis (2002). 


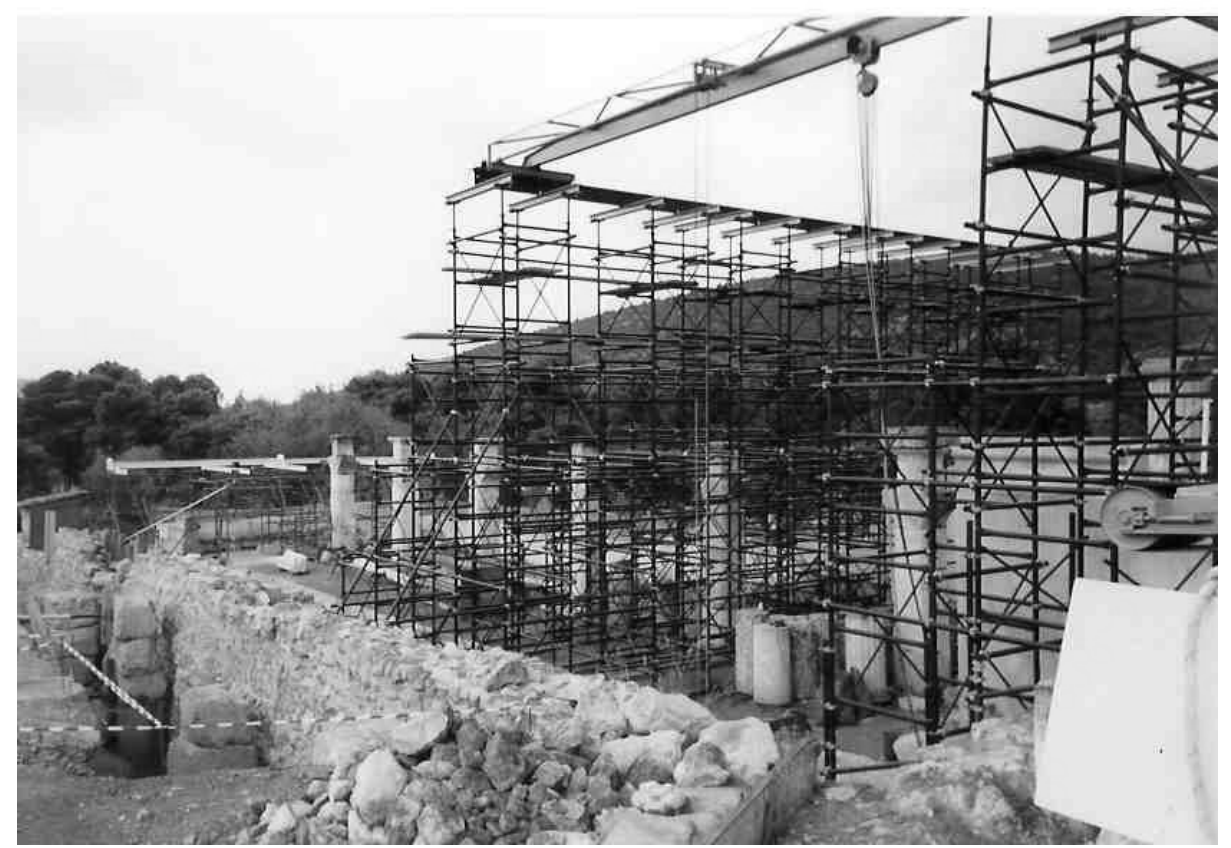

Figure 3. The Avaton Stoa of Epidaurus during its anastylosis (2002).

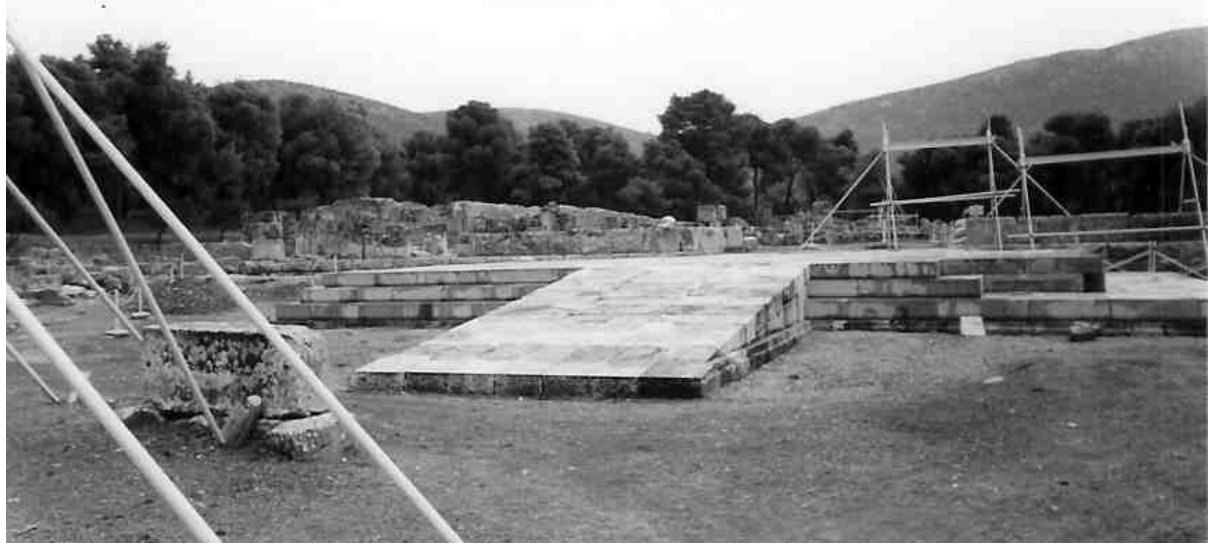

Figure 4. View of the Propylon of the Gymnasium of Epidauros, during its anastylosis (2002). 


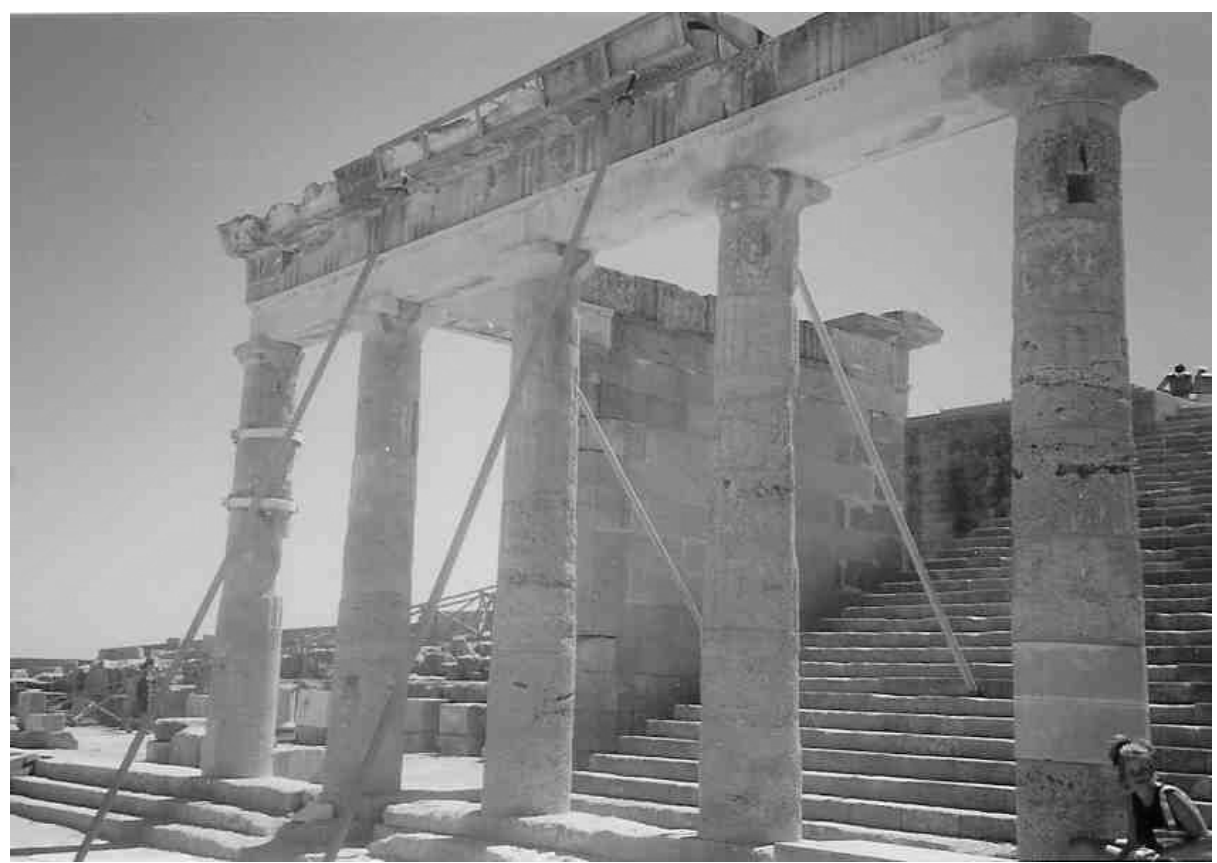

Figure 5. View of the east corner of the restored Stoa of the Acropolis of Lindos in Rhodes (2003).

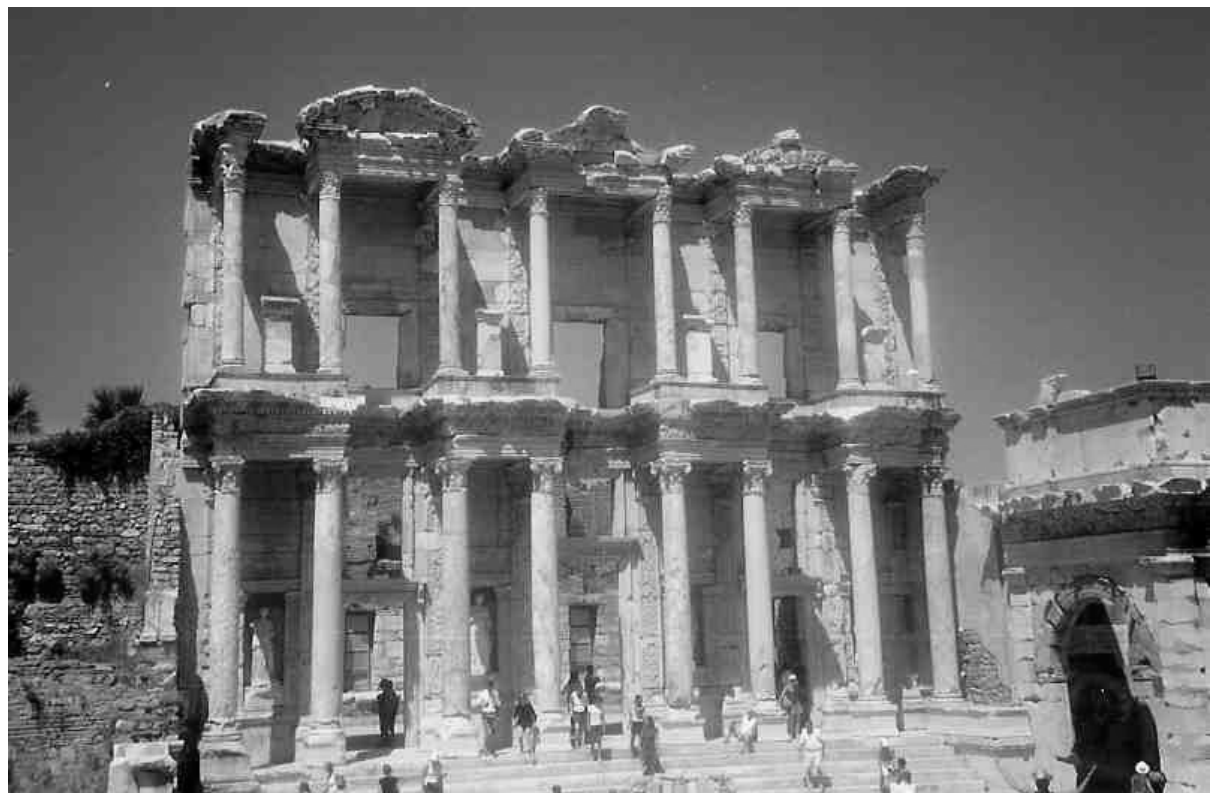

Figure 6. The façade of the Library of Celsus at Ephesus after the anastylosis (2003). 


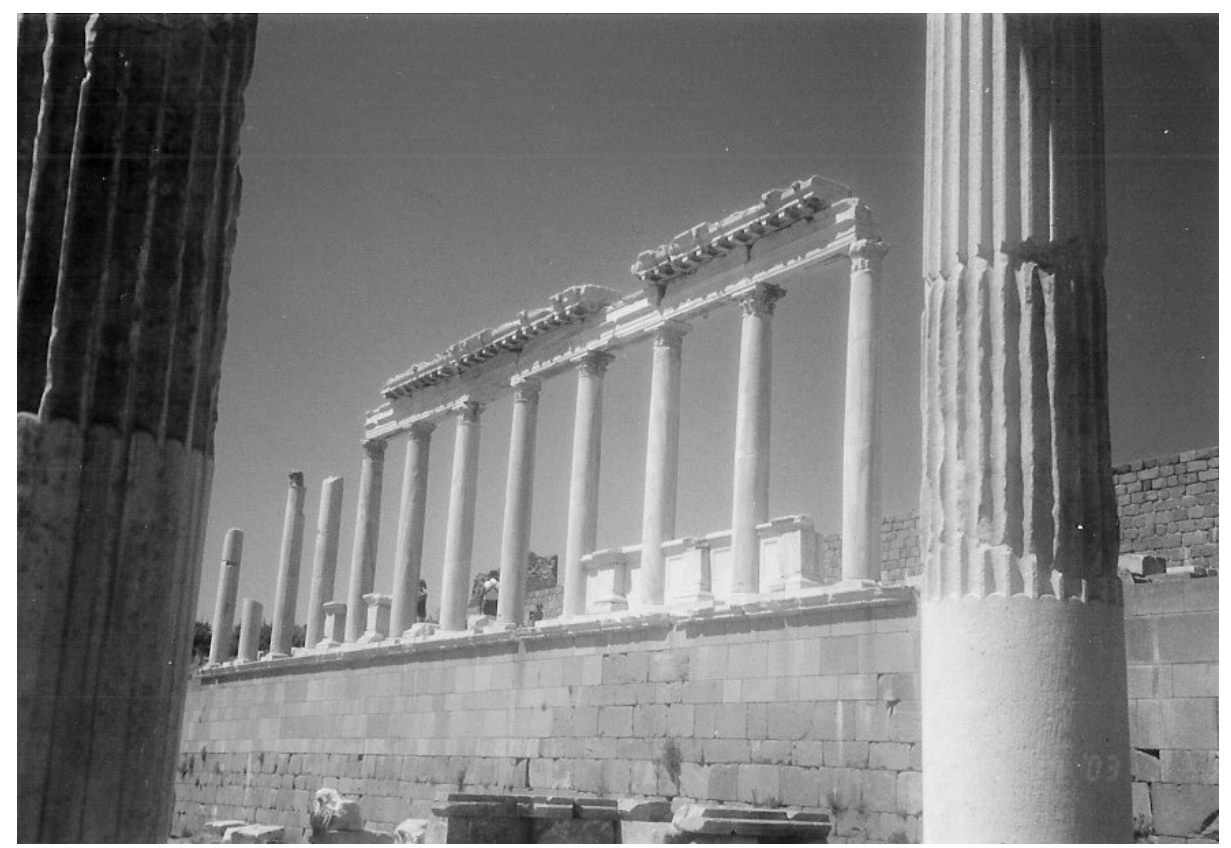

Figure 7. The temple of Trajan at Pergamun after its anastylosis (2003).

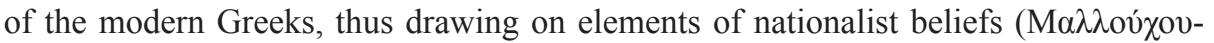
Tufano 1998: 55). Some monuments have also acquired symbolic value for contemporary society, and current restoration attempts on them reflect this symbolism (M $\pi$ oúpas 1985: 94). For example, the Celsus Library is used in a recent Turkish tourism campaign with the slogan "Discover the Undiscovered Europe". The European values with which monuments in Turkey are imbued derive from the attempts of the Turkish government to enter the European Union (Demas 1997: 131). Restoration of the site has been practised over time with this point in mind. Problems do emerge, however, when anastylosis is used to reinforce one particular identity, as this may neglect other voices within a group or community. In their responses to the survey, professionals acknowledged that symbolic values are perceived and respected differently when those restoring heritage are not local to it. For instance, Italians who had established a military presence on the island of Rhodes in the 1920s initially restored the Hellenistic Stoa of Lindos in order to legitimise their presence by promoting the idea of a Greco-Roman heritage and thus identity (Papadimitriou 1988: 170).

During the latter half of the $20^{\text {th }}$ century, the symbolic value of national heritage has received increasing emphasis in the context of universal heritage values. Inscription of monuments and sites on the World Heritage List reflects the importance of developing concepts of universality in safeguarding archaeological heritage. From a more culturespecific point of view, desire to promote cultural identity through monuments can itself instigate anastylosis, an observation highlighted by survey respondents. 


\section{Cultural Values}

In the anastylosis survey, respondents emphasised cultural values connected to issues of use, recreation and social events, and to ideas of forming a common identity, be it social, regional, national or religious (Demas 2002: 36-37). Cultural values relate to social and religious values, and consequently "heritage supports and symbolises our sociability: the way in which different parts of a society live, work together, and relate" (Mason and Avrami 2002: 16-17). At Ephesus, cultural events are performed at the site, providing the opportunity for the expression of local identities through cultural activities (Demas 1997: 130).

\section{Educational Values}

Educational values are identified in most of the anastylosis projects used as case studies in my PhD thesis (Vacharopoulou 2005), including those of the Epidaurus monuments, the Acropolis monuments, the Pergamun Trajaneum and the Celsus Library. The reassembly of the dispersed elements of a monument renders its structure more comprehensible to non-specialists (Mertens 1995: 114). When a monument is clearly interpreted, visitors understand the archaeology better (De la Torre and MacLean 1997: 9). An important debate in this regard is the critical dispute between Greek professionals on 'didactic anastylosis', a concept introduced by the Committee for the Conservation of

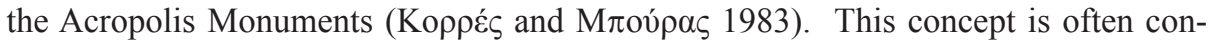
tested as it implies that education should be the primary objective of anastylosis, while

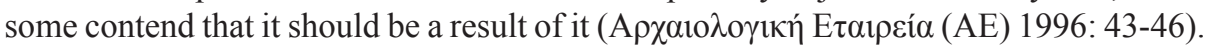
Some professionals also believe that the promotion of educational values should not be

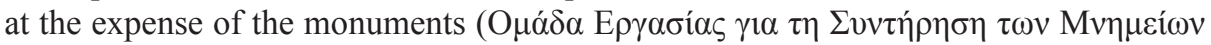

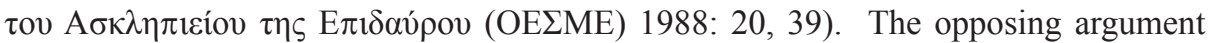
stresses that non-specialists will be prevented from experiencing the monument because they may not imagine it recomposed. Completeness of shape is primarily addressed to non-experts, as it attracts their interest and educates them (AE 1996: 76-77). However, examination of anastylosis projects undertaken in the Sagalassos Nymphaeum, the Pergamun Trajaneum and the Celsus Library indicates that while educational values are projected to the public as being of principal importance, in practice the greatest educational benefit is achieved for those involved in the project. This is partly due to anastylosis being seen as an "integral part of historic investigation" into the ancient building, and hence a form of research in itself (Patricio and Van Balen 1995: 147).

\section{Aesthetic and Artistic Values}

Anastylosis has been characterised as "ruin architecture" (Schmidt, cited in Jokilehto 1995: 70), as the destroyed monument cannot be regained and the result becomes an artificial ruin, a new construction with old fragments. In this regard, anastylosis may be considered unrealistic due to the potential for the unwitting creation of "hybrid monuments" (Giraud in AE 1996: 71).

Aesthetic and artistic values are interrelated and can be enhanced by anastylosis. However, they may not be analysed in-depth, as becomes apparent when examining the Propylon of Epidaurus (Fig. 4). In the Lindos Stoa, the Parthenon, the Celsus Library and the Sagalassos Nymphaeum, these values are prioritised and discussed analyti- 
cally so that their enhancement, via anastylosis, becomes central to the intervention. Significantly, in classical architecture artistic and aesthetic values are embodied both in the notion of the whole and the notion of parts. Therefore, preservation of the entirety is not necessary. Even when the initial function of a monument is lost, aesthetic and

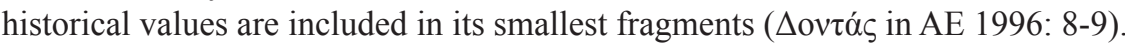

\section{Authenticity}

Artistic and aesthetic values are strongly connected with the notion of authenticity. Authenticity was initially thought to lie in originality (i.e. the presence of material original to the monument or object) and material completeness, but is now also considered to comprise more abstract attributes (Pye 2001: 58). Respect for material authenticity in anastylosis remains strong, however: the essence of ancient monuments is found in the authenticity of their materials because preservation of historical memory has been seen to depend primarily on preservation of the authentic material form (AE 1996: 79). Experiencing monuments as works of art is achieved through recognition of the authenticity of material, "since we cannot do much about the authenticity of their original form" (Giraud in AE 1996: 71).

Authenticity and integrity prove quite fundamental to anastylosis, according to the professionals' survey. In comparison with other methods of intervention, anastylosis places more focus on authenticity of place and material, and of workmanship and design. Despite questioning whether original fabrics should be accentuated (Jokilehto 1996: 73), in the case studies - especially in the Epidaurus monuments - maintenance of authenticity is focused on the original material in relation to the aesthetic result of colours and surfaces after reassembling original and new elements. Respect for authenticity was observed in the Lindos Stoa in the safeguarding of original material. In the Sagalassos Nymphaeum, authenticity was maintained in both the surviving building materials and the original structural system.

In some cases, the distinction between authenticity of material on the one hand and of form on the other creates disagreements about the correct approach. The ability to achieve authenticity seems to depend on the state of preservation of a monument; in practice, if a monument survives to a sufficient extent, focus is placed on ensuring the authenticity of its material. If it survives insufficiently, however, then authenticity becomes solely concerned with the building's form (OE $\mathrm{ME}$ 1988: 53, 95). Nevertheless, while all types of authenticity need to be assessed, the value of material originality should itself limit extensive change during interventions.

The criteria by which authenticity is judged can change with place, culture and time, thus compromise and imperfection (Lowenthal 1995: 369) are inevitable outcomes of anastylosis and should be accepted during the initial planning process. The intent of the Nara Document (ICOMOS 1994), to ensure that judgements of authenticity remain open to the range of perceptions and concepts in different contexts and settings (Stovel 1995: xxv), should also be the goal of all anastylosis projects. 


\section{Economic Values}

Economic values constitute a powerful perspective on heritage values. Indeed, any heritage site is an asset in the economic sense because "it requires investment to acquire and maintain and it yields a flow of benefits" (Mason and Avrami 2002: 17). Economics is also a major factor in conservation as it can influence decisions to intervene, shape policies and enable conservation work (Mason 1999: 4). Directly relating to the economic value of heritage is tourism. A lack of communication may be observed, however, between the tourism industry and the heritage sector, and this is aggravated by differences in the prioritisation of economic values by the two (De la Torre and MacLean 1997: 11). To a large extent excavation and anastylosis of monuments is encouraged in order to satisfy the perceived needs of visitors (Melucco Vaccaro 1996: 204). In cases where tourism has solely dictated the extent of intervention, or has developed without any control, this has proved destructive for sites and monuments (Demas 1997: 147).

Both the professionals' survey and most case studies in my $\mathrm{PhD}$ research indicate that economic values, interrelated with issues of tourism and the financial aspects of anastylosis, are disregarded in terms of their determinative role in the decision-making process. However, there is no conviction amongst professionals as to the limited role of economic values in this process. Generally, tourism and the financial aspects of anastylosis influence governments or funding bodies rather than the professionals undertaking such projects, as they are mainly concerned with the implementation of the projects rather than the economic benefits deriving from the completion of these projects. Professionals admit that the lack of or limitations in funding can influence decisions on materials (e.g. cheaper material might be employed) and personnel (e.g. limitations in numbers employed, which may delay works), while creation of jobs and funding availability are not as influential. However, examination of my case studies reveals that tourism - as an embodiment of economic values - is influential because it forms a major source of income for the countries concerned. In Greece, tourism is never explicitly stated as a factor influencing conservation decisions, but it is always in the background, as demonstrated by the importance attached to education, improvement of legibility and interpretation of monuments for the visiting public. Conversely in Turkey, especially in the Sagalassos Nymphaeum and the Pergamun Trajaneum, promotion of tourism was openly included among the aims of anastylosis intervention.

\section{Processes and Complications in Value-Assessments}

The prioritisation of a monument's values, as identified and attributed by professionals and stakeholders, should be the first step before the process of anastylosis itself. In the case of the Parthenon, enhancement of the monument's values was projected as the reason for proposed intervention (M $\pi$ ov́ $\alpha \varsigma$ 1983a: 401-405). As suggested above, the variety of value-types are not always easily ranked and this can create conflicts in decision-making, for example prioritising between symbolic and scientific values or between artistic and educational ones (M $\pi$ ov́ $\rho \alpha_{\varsigma}$ 1983b: 418-419). Certain values of classical monuments, such as artistic values, are readily apparent to the observer, while others, such as scientific values, derive mainly from archaeological research and are therefore less obvious to the non-specialist, rendering the approach to anastylosis a complex decision-making process. Generally, as disclosed by the professionals ques- 
tioned, almost all types of values are taken into consideration when applying anastylosis. All professionals agreed that values should initially be assessed, and that only after this should decisions be made. This approach was followed in the anastylosis of the Sagalassos Nymphaeum, where detailed commissioned drawings emphasised the monument's aesthetic and historical values (Patricio 1996: 107).

\section{Suggestions for Better Practice in the Application of Anastylosis}

The usefulness of the concept of values has long been recognised in heritage preservation, since awareness of ascribed values can indicate suitable conservation treatments (Pye 2001: 61). Anastylosis is considered an activity that can result both in long-lasting preservation and in making monuments comprehensible for visitors (Schmidt 1997: 50). However, it is important that heritage professionals also protect the scientific value of the archaeological record, and present it in a "visually stimulating and thought-provoking manner", while "maintaining historical accuracy and respecting the integrity of the ruins" (Sivan 1997: 52).

It is also necessary to involve the public in the identification and prioritisation of values (Jokilehto 1999: 292). In addition to the views of archaeologists, conservators and other specialists, it is important to understand the views of non-professional stakeholders and what they value and want to preserve (Clark 2001: 15). These stakeholders should be engaged early on and throughout the planning process (Mason and Avrami 2002: 19). Such communication can be empowering for heritage managers as it can provide fresh perspectives and opportunities for new ways of doing things. Communication can also trigger political support for heritage management schemes by local communities as their confidence in such systems increases due to opening channels of communication (Hall and McArthur 1998: 221).

Meeting these needs entails developing a management plan that is value-based in its approach to manage and conserve or restore a site. The aims of holistic management should include "an ideological basis in establishing identity, linked with its educational function, an economic basis in tourism, and an academic function in safeguarding the heritage database" (Cleere 1989: 10). However, the principal objective of heritage management should be to preserve the cultural significance of a site, as determined by the values society perceives in it. Communities that value and own their heritage resource become central to management decisions, but their involvement is not yet fully developed (Hall and McArthur 1998: 57-58).

In light of the above, effective management may be seen to evolve in four steps:

1. Location, identification and documentation of resources

2. Assessment of the values or significance of the site

3. Planning and decision-making aimed at conserving cultural significance

4. Implementation of decisions

(after Pearson and Sullivan 1999: 8-9) 
All stakeholders can contribute to decisions on whether to carry out an anastylosis project, and on which monument(s) of the site, as well as to the process of undertaking the project and establishing its aims and extent.

In addition to value assessment the third stage, planning and decision-making, also includes prioritisation of the different values. To achieve balanced decisions and the sustainability of conservation efforts there is a need for increased cooperation among professionals, decision makers and community members. Giving voice to these varied perspectives ensures that conservation is responsive to professional and academic ideals, as well as to social needs and concerns.

\section{Conclusion}

The challenges of conservation derive not only from heritage sites and monuments themselves, but also from evaluating the contexts in which society places them. These contexts form the real source of meaning for heritage and the raison d'etre for conservation (Avrami et al. 2000: 4). Anastylosis has become a type of intervention in which contemporary ideas of heritage management and conservation influence, or should influence, implementation. It should be part of a holistic management process and system that thoroughly assesses the values of archaeological sites, and establishes a framework for intervention only after exploring the monument's significance. Overall, value assessments can aid decisions when selecting monuments for anastylosis and for establishing the extent of this intervention itself. For example, monuments may be selected for anastylosis in order to enhance their architectural and archaeological values. Importance placed on educational values may result in extending the anastylosis in parts of the monument where little original material survives, while aesthetic value judgements may limit extensive interventions. In general, however, there is a tendency to appreciate these types of values and neglect others, such as cultural and symbolic values. This is why an all-inclusive assessment of values and significance are essential in deciding, planning and implementing anastylosis. Such decisions need to be based on a compromise of value judgements balanced to satisfy all stakeholders, professional and non-professional.

\section{Acknowledgements}

I would like to thank the PIA Committee for giving me the opportunity to write and present this paper. I would also like to express my gratitude to Prof. Clifford Price (Institute of Archaeology, UCL (IoA)), and Tim Williams (IoA), for their excellent guidance and advice in supervising my $\mathrm{PhD}$ research on anastylosis. I would like to thank the Graduate School and the Institute of Archaeology, UCL, for providing financial support to visit the archaeological sites in which my case studies are found. Special thanks should go to all those professionals who enthusiastically participated in the anastylosis survey and provided me with an insight into anastylosis theories and practices. 
References

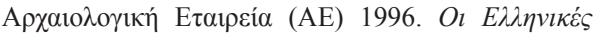

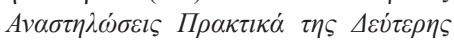

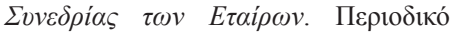

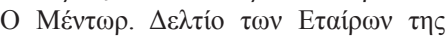

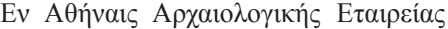
9(37).

Avrami, E., Mason, R. and de la Torre, M. 2000. Report on Research, in Avrami, E., Mason, R., and de la Torre, M. (eds.) Values and Heritage Conservation: Research Report. Los Angeles: Getty Conservation Institute, 3-12.

Bluestone, D., Klamer, A., Throsby, D. and Mason, R. 1999. The Economics of Heritage Conservation: A Discussion, in Getty Conservation Institute (ed.) Economics and Heritage Conservation: A Meeting Organised by the Getty Conservation Institute, December 1998. Los Angeles: Getty Conservation Institute, 19-22.

Carter, B. and Grimwade, G. 1996. Balancing Use and Preservation in Cultural Heritage. International Journal of Heritage Studies, 3(1), 45-53.

Clark, K. 2001. Informed Conservation: Understanding Historic Buildings and their Landscapes for Conservation. London: English Heritage.

Cleere, H. 1989. Introduction: The Rationale of Archaeological Heritage Management, in Cleere, H. (ed.) Archaeological Heritage Management in the Modern World. London: Unwin-Hyman, 1-19.

De la Torre, M. and MacLean, M. 1997. The Archaeological Heritage in the Mediterranean Region, in De la Torre, M. (ed.) The Conservation of Arcaeological Sites in the Mediterranean Region. An International Conference Organised by the Getty Conservation Institute and the J. Paul Getty Museum, 6-12 May 1995. Los Angeles: Getty Conservation Institute, 5-14.

Demas, M. 1997. Ephesus, in de la Torre, M. (ed.) The Conservation of Archaeological Sites in the Mediterranean Region: An International Conference Organised by the Getty Conservation Institute and the J. Paul Getty Museum. May 1995. Los Angeles: Getty Conservation Institute, 127-149.
Demas, M. 2002. Planning for Conservation and Management of Archaeological Sites. A Values-Based Approach, in Teutonico, J. M. and Palumbo, G. (eds.) Management Planning for Archaeological Sites: Proceedings of an International Workshop Organised by the Getty Conservation Instiutte and Loyola Marymount University, May 2000, Corinth, Greece. Los Angeles: Getty Conservation Institute, 27-54.

Erder, C. 1986. Our Architectural Heritage: From Consciousness to Conservation. Paris: United Nations Educational, Scientific and Cultural Organisation (UNESCO).

Feilden, B. M. 1994. Conservation of Historic Buildings. London: Butterworth-Heinemann.

Gazzola, P. 1972. Restoring Monuments: Historical Background, in UNESCO Preserving and Restoring Monuments and Historic Buildings. Paris: UNESCO, 15-30.

Getty Conservation Institute 1999. Economics and Heritage Conservation: A Meeting Organised by the Getty Conservation Institute, December 1998. Los Angeles: Getty Conservation Institute.

Hall, C. M. and McArthur, S. 1998. Integrated Heritage Management: Principles and Practice. London: The Stationery Office.

International Council on Monuments and Sites (ICOMOS) 1964. International Charter for the Conservation and Restoration of Monuments and Sites (The Venice Charter). [http://www.international.icomos. org/charters/venice_e.htm] [Accessed March 2005].

ICOMOS 1994 Nara Document on Authenticity. [http://www.international.icomos.org/ charters/nara_e.htm] [Accessed March 2005].

ICOMOS 1999. The Australia ICOMOS Charter for the Conservation of Places of Cultural Significance (The Burra Charter). [http://www.icomos.org/Australia/] [Accessed March 2005].

Jokilehto, J. 1995. Review of Reconstruction of Ancient Ruins, by H. Schmidt. Conservation and Management of Archaeological Sites, 1, 69-71. 
Jokilehto, J. 1996. International Standards, Principles Loyola Marymount University, May 2000, Corand Charters of Conservation, in Marks, S. (ed.) Concerning Buildings: Studies in Honour of Sir Bernard Feilden. London: Butterworth-Heinemann, 55-81.

inth, Greece. Los Angeles: The

Getty Conservation Institute, 13-26.

Jokilehto, J. 1999. A History of Architectural Conservation. London: Butterworth Heinemann.

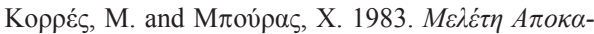

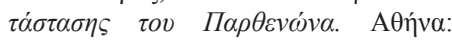

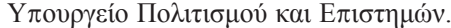

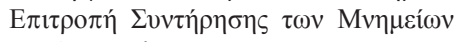
$\tau \eta \varsigma$ Акроло́ $\lambda \eta \varsigma$

Mertens, D. 1995. Planning and Executing Anastylosis of Stone Buildings, in Stanley-Price, N. P. (ed.) Conservation on Archaeological Excavations. With Particular Reference to the Mediterranean Area. Rome: ICCROM, 113-134.

Cleere, H. (ed.) Archaeological Heritage Management in the Modern World. London: Unwin-Hyman, 23-29.

Lowenthal, D. 1995. Managing the Flux of Authenticity, in Larsen, K. E. (ed.) Proceedings of the Nara Conference on Authenticity. Nara, Japan, November 1994. UNESCO, International Centre for the Study of the Preservation and Restoration of Cultural Property (ICCROM) and ICOMOS, 369-370.

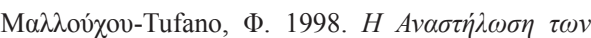

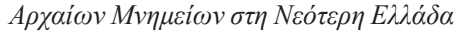

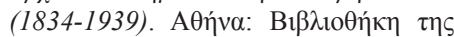

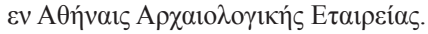

Marks, S. (ed.) 1996. Concerning Buildings: Studies in Honour of Sir Bernard Feilden. Lon- M don: Butterworth-Heinemann.

Mason, R. 1999. Economics and Heritage Conservation: Concepts, Values, and Agendas for Research, in Getty Conservation Institute (ed.) Economics and Heritage Conservation: A Meeting Organised by the Getty Conservation Institute, December 1998. Los Angeles: Getty Conservation Institute, 2-18.

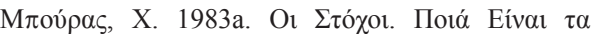

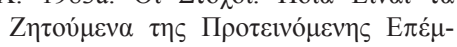

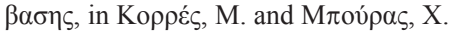

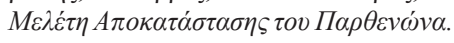

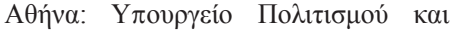

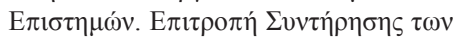

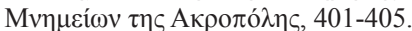

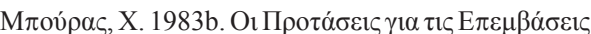

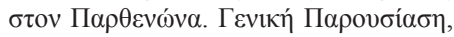

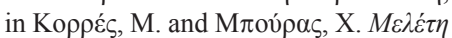

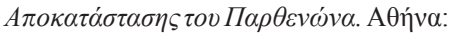

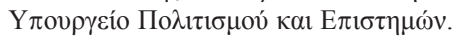

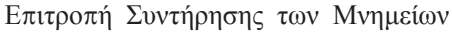

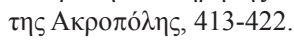

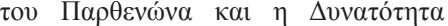

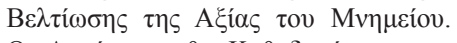

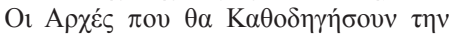

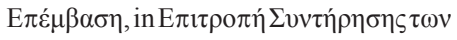

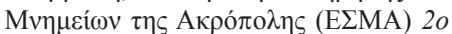

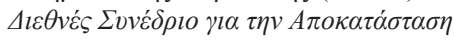

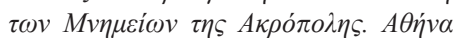

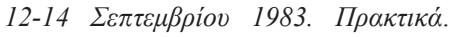

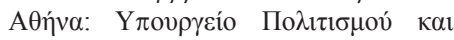

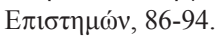

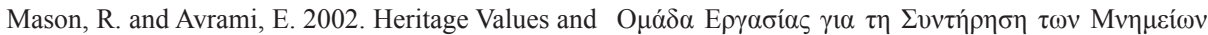
Challenges of Conservation Planning, in Teutonico, J. M. and Palumbo, G. (eds.) Management Planning for Archaeological Sites: Proceedings of an International Workshop Organised by the Getty Conservation Institute and 
Papadimitriou, V. 1988. The Anastylosis of the An- Pye, E. 2001. Caring for the Past: Issues in Consercient Monuments on the Acropolis of Lindos: Past and Present Attempts, in Dietz, S. and Papachristodoulou, I.

(eds.) Archaeology in the Dodecanese. Schmidt, H. 1997. Reconstruction of Ancient BuildCopenhagen: The National Museum of Denmark, 169-171.

Patricio, T. C. 1996. The Nymphaeum at Sagalassos, Turkey: The Anastylosis and the Applicability, in ICOMOS International Committee on Archaeological Heritage Management (ICAHM) (ed.), Archaeological Remains, In Situ Preservation: Sivan, R. 1997. The Presentation of ArchaeologiProceedings of the Second ICAHM International Conference, Montreal, Quebec, Canada, October 11-15, 1994. Ottawa: ICAHM Publications, 101-109.

Patricio, T. and Van Balen, K. 1995. Architectural Analysis of the Late Hellenistic Nymphaeum at Sagallasos: First Results, in Waelkens, M. and Poblome, J. (eds.) Sagalassos III: Report on the Fourth Stovel, H. 1995. Working Towards the Nara DocuExcavation Campaign of 1993. Leuven: Leuven University Press, 143-147.

Pearson, M. and Sullivan, S. 1999. Looking After Heritage Places: The Basics of Heritage Planning for Managers, Landowners and Administrators. Melbourne: Stovel, H. 2001 Notes on Authenticity. [http://www. Melbourne University Press.

Philippot, P. 1996. Restoration from the Perspective of the Humanities, in Stanley-Price, N., Kirby Talley, M. Jr. and Melucco Vaccaro, A. (eds.) Historical and Philosophical Issues in the Conservation of Cultural Heritage: Readings in Conservation. Los Angeles: Getty Conservation Institute, 216-229. cal Sites, in De la Torre M. (ed, The Conservation of Archaeological Sites in the Mediterranean Region: An International Conference Organised by the Getty Conservation Institute and the J. Paul Getty Museum, 6-12 May 1995. Los Angeles: Getty Conservation Institute, 51-59.

ment, in Larsen, K. E. (ed.) Proceed-
ment ings of the Nara Conference on Authenticity. Nara, Japan, November 1994. UNESCO, ICCROM and ICOMOS, xxxiii-Xxxvi. unescobkk.org/culture/vietnam workshop2001/herb_stovel.pdf] [Accessed April 2001]. 